\title{
Features of Development and Implementation of Potential of Credit Institutions in the Arctic Regions of the Russian Federation
}

\author{
Roman V. Badylevich ${ }^{1 *[O R C I D}$ 0000-0002-3164-8745], \\ Elena A. Verbinenko 1[ORCID 0000-0003-3709-2116]
}

\author{
${ }^{1}$ Luzin Institute for Economic Studies - Subdivision of the Federal Research Centre "Kola Science Centre of the \\ Russian Academy of Sciences», Apatity, Russia \\ ramapatit@rambler.ru
}

\begin{abstract}
The article is devoted to the study of features of formation and implementation of potential of credit institutions in the regions of the Russian Arctic. The role and place of commercial banks in investment processes at the regional level was investigated. The factors influencing the investment activity of commercial banks in the regions are revealed. The potential of credit institutions in the regions of the Russian Arctic was analyzed, the problems of using the credit potential in these regions were studied. The features of the Russian Arctic, influencing the performance of the market of credit institutions, are indicated. It was determined that, in recent years, in the regions of the Russian Arctic there was a decrease in the number of regional banks and branches of capital credit institutions. The assessment of the established resource base of the banking sector by credit institutions was carried out. The presented dynamics of customer funds attracted by credit institutions and their divisions located in the regions of the Russian Arctic in 2012-2021 testifies to the different growth rates of this indicator in comparison with the average Russian level in individual Arctic regions. Analysis of the dynamics of the ratio of lending to the real sector of the economy to the established base of credit institutions made it possible to identify the regions of the Russian Arctic, in which the lending activity of the banking sector in relation to the real sector of the economy corresponds to the established base, and those where it is insufficient. A comparison was made of the structure of lending to legal entities and individual entrepreneurs by types of economic activity in the regions of the Russian Arctic and in Russia as a whole. Measures are proposed to enhance the participation of the banking sector in investment processes and increase the participation of credit institutions in the development of a sufficient financial base to ensure the development of the regions of the Russian Arctic.
\end{abstract}

Keywords: banking resources, investment activities, potential of credit institutions, regional development, the Russian Arctic

\section{INTRODUCTION}

Currently, the issues of the rational organization of the financial systems of the regions and the sufficiency of financial resources to ensure the specified rates of regional development are of particular relevance. In conditions when the focus on the centralization of financial flows across the country remains, while there is an increase in the need of regions for additional financial resources for the anti-crisis policy and the achievement of the specified volumes of investment activity, the importance of the full implementation of the developed financial and investment potential of each constituent entity of the Russian Federation is increasing.

The potential of credit institutions is one of the components of the overall financial and investment potential of the region. It is a set of financial resources that can be accumulated by credit institutions and used as an investment base for the region. The potential of credit institutions is a strategically important resource for ensuring sustainable economic development of the territorial system [1]. 
Abroad, the share of bank resources in investments in fixed assets reaches $2 / 3$ of the total (for example, the share of borrowed capital in the structure of investment financing sources is $40 \%$ in the United States, about $65 \%$ in Japan, about $45 \%$ in Europe) [2]. In Russia, the participation of the banking sector in investment activities remains low. This is confirmed by the data of official statistics, according to which in 2019-2020 the share of bank lending in investments in non-financial assets in our country was at the level of $9.7 \%-9.8 \%$ [3], and by the results of numerous studies $[4,5]$. This situation is due to a number of factors, including the instability of the general economic situation, which does not allow banks to focus on long-term investment projects in the implementation of credit policy, high cost of credit resources, more favorable conditions for attracting investment capital for large business entities from alternative sources [6]. The growth rate of banking participation in investment activity is also limited by the weak willingness of the real sector of the economy to invest, due to stagnation of productivity and the lack of competitive industries.

Another specific feature of bank lending in our country is significant differences in the degree of participation of credit institutions in investment processes in the regional context. If in some constituent entities of the Russian Federation the share of bank loans in investments exceeds $30 \%$ (for example, in Oryol and Tula Regions), in others it does not even reach $2 \%$ (the Republic of Komi, the Republic of Sakha) [3]. This differentiation requires an in-depth study of the peculiarities of organizing the participation of the banking sector in investment processes in the constituent entities of the Russian Federation, which are classified as priority development areas and are characterized by a high need for financial resources to achieve the specified parameters of investment activity. Such constituent entities include the regions of the Russian Arctic [7].

\section{MATERIALS AND METHODS}

The purpose of this study is to identify the specifics of the implementation of the financial potential of credit institutions in the regions of the Russian Arctic. To achieve this goal in the study, it is necessary to solve the problems associated with determining the features of the development of the resource base of the banking sector of this group of regions, researching the priority areas of using bank capital, as well as assessing the degree of participation of credit institutions in investment activities.
To achieve the research goal and to solve the set tasks, economic methods of analysis are used, including vertical and horizontal analysis, a comparison method, a graphical method for presenting data, methods of grouping, synthesis and generalization.

The methodology of the analysis presented in the study was detailed by the authors in previously published works $[8,9]$.

Research time period is 2011-2021.

Statistical data presented on the website of the Central Bank of the Russian Federation, as well as official data from Rosstat, were used as an information base for the study.

\section{RESULTS}

Currently, the Russian Arctic includes the entire territory of four regions (Murmansk Region, Nenets, Yamalo-Nenets and Chukotka Autonomous Districts) and partially the territories of five regions (the Republics of Sakha (Yakutia), Karelia, Komi, Krasnoyarsk Territory and Arkhangelsk Region).

The features of the Russian Arctic that affect the performance of the banking sector in these regions include:

- significant territorial remoteness from the financial centers of the country;

- low population density and the presence of hard-to-reach settlements on the territory of the regions of the Russian Arctic;

- low level of development of small businesses, the prevalence of large industrial enterprises in the structure of the economy, that are part of industrial and financial groups and holdings, and have access to alternative credit sources of financing for investment projects;

- the decisive economic role of the extractive industries, which form a significant part of the gross regional product of the constituent entities of the Russian Arctic;

- high investment potential of the regions of the Russian Arctic, which is due to the implementation of large state infrastructure projects in the Arctic, as well as the implementation of large-scale projects in the field of exploration and production of natural resources by companies in the fuel and energy complex.

Over the past decade, the number of regional 
banks, as well as branches of banks registered in other constituent entities of the Russian Federation, has significantly decreased in the regions of the Russian Arctic (Figure 1).

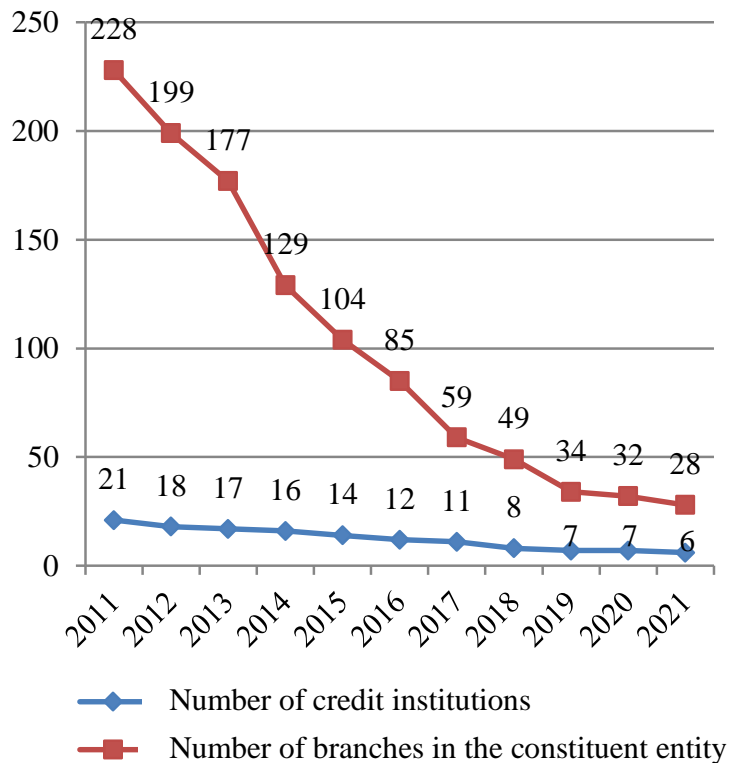

Figure 1. Dynamics of the number of regional banks and branches registered in the regions of the Russian Arctic in 2011-2021, units

Source: Compiled by the authors based on the data [10]
At the same time, it should be noted that in all regions of the Russian Arctic, the provision of the population with operating credit institutions and their subdivisions is at least not lower than the average for the Russian Federation.

We will assess the formed resource base of the banking sector (Figure 2). Over the period under review, in the Russian Arctic as a whole, the volume of the resource base formed by credit institutions increased 2.8 times. This dynamics is lower than the growth rates of customer funds attracted by the banking sector in Russia as a whole (the same indicator for the Russian Federation was 3.1 times).

It should be noted that the dynamics of attracted resources in individual regions of the Russian Arctic in the last decade has been uneven. The regions with higher growth rates of this indicator in comparison with the average Russian level include YamaloNenets Autonomous District. The group with low growth rates of the resource base of the banking sector includes the Komi Republic, Arkhangelsk and Murmansk Regions, Chukotka Autonomous District. In the structure of funds attracted by credit institutions, the largest share (more than 30\%) falls on the Krasnoyarsk Territory, which is home to more than a third of the total population of the regions included in the Russian Arctic.

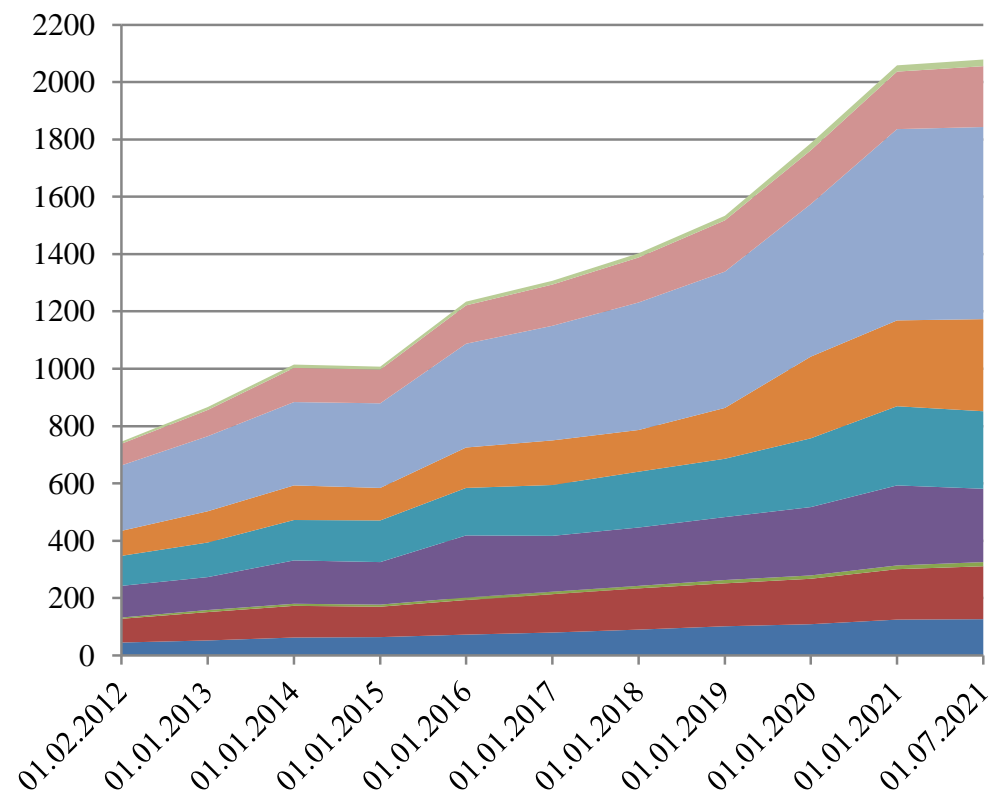

Chukotka Autonomous District

- The Republic of Sakha (Yakutia)

- Krasnoyarsk Territory

- Yamalo-Nenets Autonomous District

- Murmansk Region

- Arkhangelsk Region without data on Nenets Autonomous District

- Nenets Autonomous District

- Komi Republic

- Republic of Karelia

Figure 2. Dynamics of customer funds attracted by credit institutions and their divisions located in the regions of the Russian Arctic in 2012-2021, million rubles

Source: Compiled by the authors based on the data [10]

Assessing the formed resource base of credit institutions, we should note its low size per capita.
At the beginning of 2021, the values of the ratio of attracted customer funds to the population (per 1000 
population) on average in the regions of the Russian Arctic and in Russia as a whole amounted to 266.7 and 504.7, respectively. The only region of the Russian Arctic, where this indicator turned out to be higher than the average Russian level, is YamaloNenets Autonomous District.

Another feature of funds attracted from customers by credit institutions in the regions of the Russian Arctic is the prevalence of funds from individuals over funds from corporate clients. If in the regions of the Russian Arctic, individuals account for about $62-65 \%$ of the total volume of the formed resource base, in the Russian Federation the same indicator is $35-40 \%$. This is due, on the one hand, to the high level of income of the population in the regions of the Russian Arctic and, accordingly, to significant savings, and, on the other hand, to a trend towards the withdrawal of significant financial resources to the capital regions by large resource companies operating in the Arctic, and a weak development of small and medium-sized businesses.
In 2020-2021, in the structure of attracted funds, there was an increase in the share of customer funds on current accounts, and a simultaneous decrease in customer resources on time deposits. The catalyst for this situation was the policy of the Central Bank of the Russian Federation, in particular, the establishment of a low key rate, the value of which was at the level of 4.25-4.5\% for most of 2020-2021. This policy led to a significant decrease in the attractiveness of bank deposits as a tool for preserving and increasing capital for the population.

At the same time, in the past two years the outflow of funds from time deposits in the Russian Arctic regions has been fully compensated by the increase in funds on brokerage accounts, escrow accounts and other products.

It is possible to identify the features and trends in the use of the formed potential of credit institutions based on an assessment of their credit activity in the regions where they are located (Figure 3).

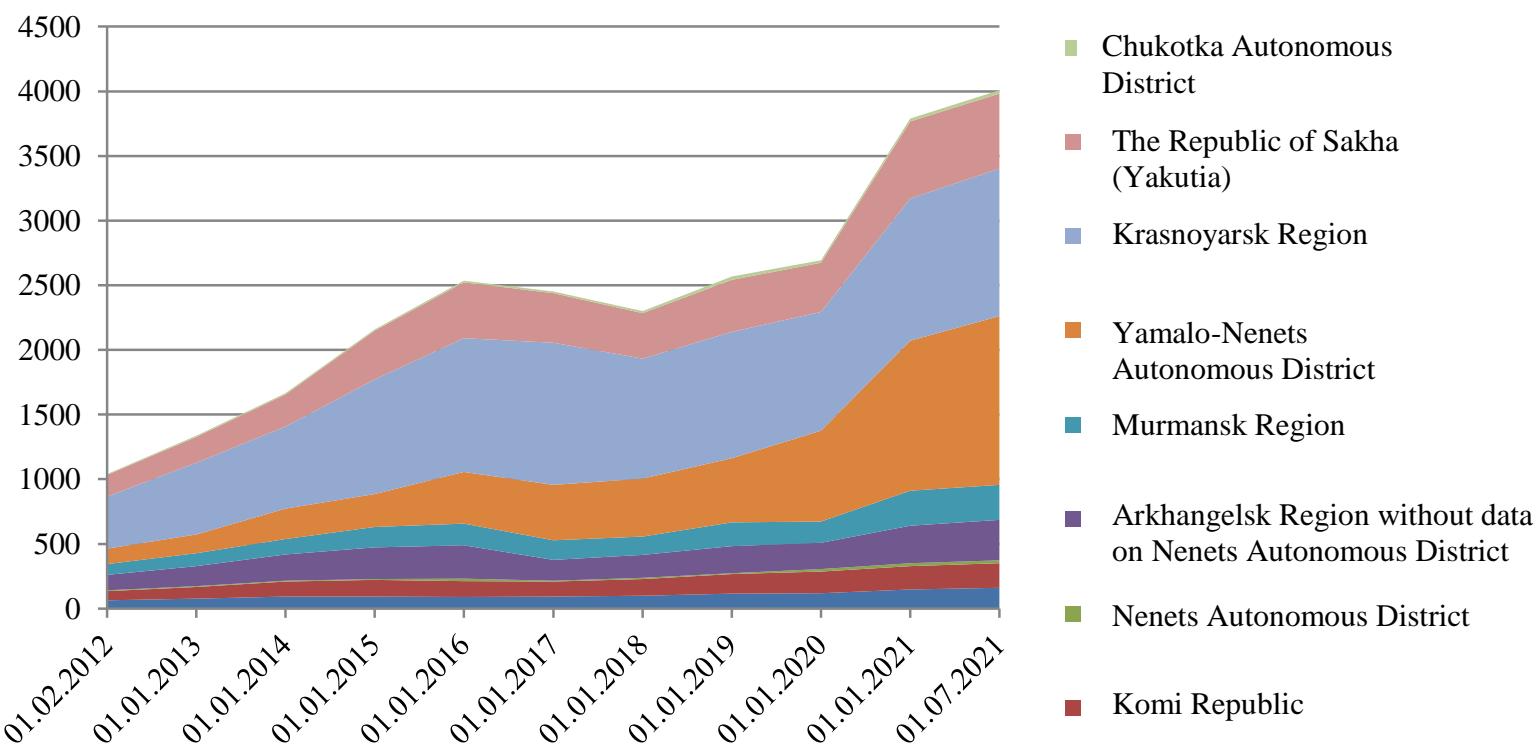

Figure 3. Dynamics of debt on loans issued by credit institutions and their divisions located in the regions of the Russian Arctic in 2012-2021, million rubles

Source: Compiled by the authors based on [10]

In contrast to the attracted resources, the debt on bank loans changed less evenly. The most significant growth in lending is characteristic of 2012-2015 and 2020, which generally coincides with the direction of the dynamics of changes in debt on loans in Russia as a whole.

Since 2012, the growth in lending in the regions of the Russian Arctic as a whole has significantly exceeded similar indicators in Russia. The total debt on loans increased 3.9 times (2.7 times in Russia). In many ways, the indicated growth in the Arctic regions was due to an increase in issued loans by more than 1.5 times in three regions (YamaloNenets Autonomous District, the Republic of Sakha (Yakutia) and Murmansk Region) in 2020.

In 2012-2021, uneven dynamics of lending across the Arctic regions led to the fact that the share of Yamalo-Nenets Autonomous District in the total debt of the constituent entities of the Russian Arctic significantly increased. By mid-2021, this region 
accounted for more than $1 / 3$ of the total volume of debt on loans issued in the regions of the Russian Arctic (at the beginning of 2012, the same value was less than 12\%).

The intensity of bank lending in the Arctic regions relative to the average level in the Russian Federation can be estimated based on the ratio of the volume of debt on loans to the population in the constituent entity of the Russian Federation or to the level of the gross regional product (GRP) produced (Figure 4). In terms of the ratio of debt on loans to GRP, the regions of the Russian Arctic are significantly inferior to the average Russian level, while the dynamics of this indicator for the Arctic regions and for Russia as a whole coincides. In addition, it should be noted that among the Arctic subjects there are no regions where the value of this indicator is higher than in the Russian Federation.

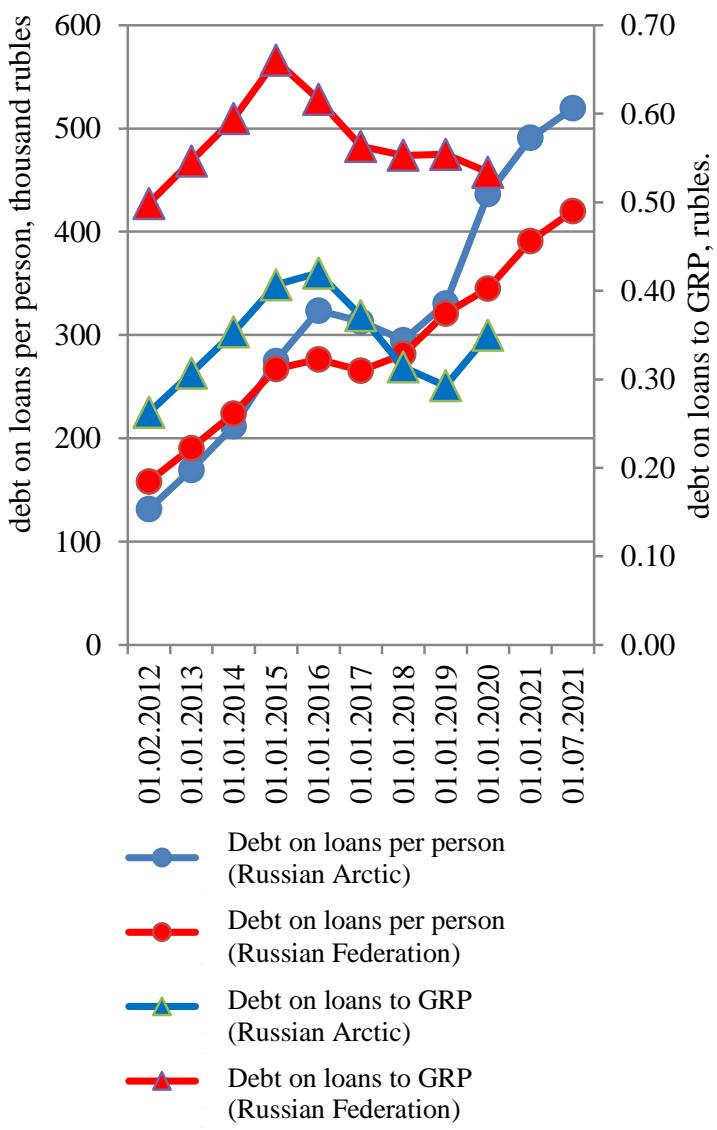

Figure 4. Relative indicators of the intensity of bank lending in the regions of the Russian Arctic and the Russian Federation as a whole in 2012-2021

Source: Calculated by the authors based on the data [10]

In contrast to the ratio of debt on loans to GRP, the indicator of the volume of lending per person in the regions of the Russian Arctic since 2015 is higher than the average for the Russian Federation. It should be noted that the maximum amount of debt on bank loans per person for the subjects of the Russian Arctic is noted in the Yamalo-Nenets Autonomous District (in 2021, the value for this subject exceeded the average Russian level by 4.5 times).

Until 2019, the structure of debt on bank loans for the Arctic regions was characterized by a higher share of indebtedness of individuals in comparison with Russia as a whole, but in the last two years the share of indebtedness of individuals in the country as a whole increased from $25-30 \%$ to $35 \%$, and in the Arctic regions, on average, it decreased from 40$43 \%$ to $36 \%$. But at the same time, the change in the structure of bank lending in the regions of the Russian Arctic was almost entirely due to a decrease in the share of indebtedness of individuals in Yamalo-Nenets Autonomous District (over ten years in this region, the share of individuals in the structure of bank lending decreased from $38 \%$ to $15 \%$ ). Thus, at present, in most of the regions of the Russian Arctic, the balance of bank lending is shifted towards lending to the population and does not correspond to the structure of lending in Russia.

From the standpoint of assessing the use of the potential of credit institutions, it is of interest to analyze the dynamics of the ratio of lending to the real sector of the economy to the established base of credit institutions, excluding funds in settlement accounts. The dynamics of this ratio is shown in Figure 5. The presented data make it possible to single out the regions of the Russian Arctic, in which the lending activity of the banking sector in relation to the real sector of the economy corresponds to the established base, and those regions where it is insufficient.

In particular, the indicators of lending to the real sector of the economy in comparison with the formed resource base are quite high in YamaloNenets Autonomous District, the Republic of Sakha (Yakutia), and Krasnoyarsk Territory. The opposite situation is observed in Murmansk and Arkhangelsk Regions, the Republics of Komi and Karelia. In these regions, the investment activity of credit institutions is insufficient, and the banking sector, represented mainly by divisions of the capital's banks, formulates a mechanism for "pumping" resources from the constituent entities of the Russian Federation to the financial centers of Russia. In Nenets and Chukotka Autonomous Districts, the dynamics of the analyzed indicator is spasmodic and cannot be assessed unambiguously. 


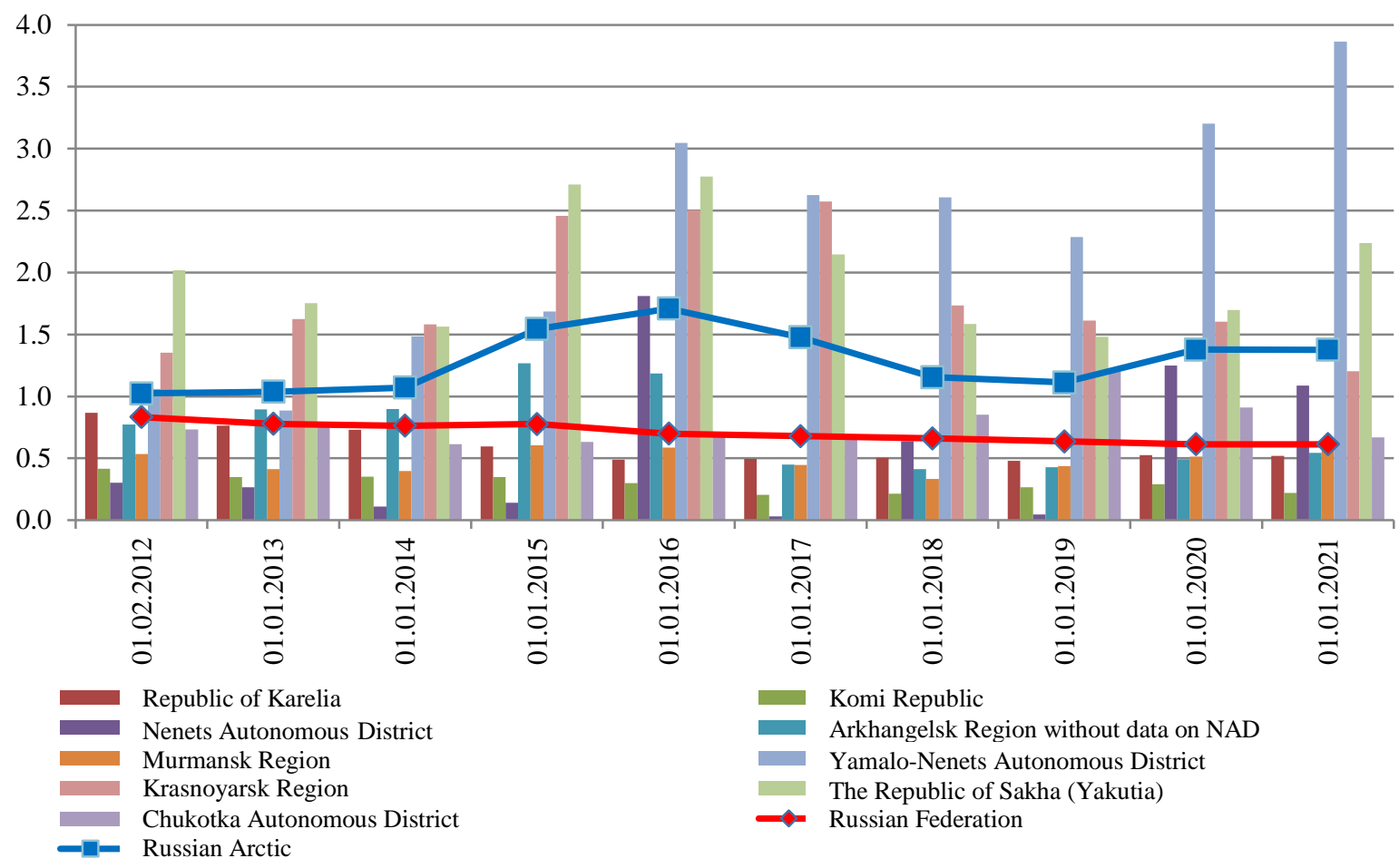

Figure 5. The ratio of debt on loans provided to resident legal entities and individual entrepreneurs to deposits and other funds received from legal entities and individuals in the regions of the Russian Arctic and the Russian Federation as a whole in 2012-2021

Source: Calculated by the authors based on the data [10]

It is interesting to compare the structure of lending to legal entities and individual entrepreneurs by type of economic activity in the regions of the Russian Arctic and in Russia as a whole.

At the beginning of 2021, in four Arctic regions of the Russian Federation (the Republic of Komi, the Republic of Sakha (Yakutia), Yamalo-Nenets and Nenets Autonomous Districts), the proportion of lending was significantly shifted towards lending to the mining industry. In three other regions, lending to processing industries (wood processing and production in the Republic of Karelia, pulp and paper production in Arkhangelsk Region, metallurgical production in Krasnoyarsk Territory) predominated in the structure of the debt of legal entities and individual entrepreneurs. In the Murmansk region, a large share of lending falls on entities associated with maritime activities, and in Chukotka Autonomous District it falls on wholesale and retail trade.

At the same time, almost all Arctic regions (with the exception of Murmansk Region) are characterized by a low share of credit debt of small and medium businesses in the total debt on bank loans.

\section{DISCUSSION}

The highlighted features of the implementation of the financial potential of credit institutions in the regions of the Russian Arctic make it possible to propose measures to enhance the participation of the banking sector in investment processes. The authors suggest the following as such measures for further discussion.

1) Consider the possibility of creating the Arctic Development Bank, a large financial institution with state participation, the main purpose of which will be to attract and concentrate private capital, including banking, for the implementation of largescale investment projects (see details [11]).

2) Take a number of steps to support regional banks, whose activities are aimed at stimulating investment activity in the constituent entities, in particular in the regions of the Russian Arctic (see details [12])

3) Intensify the participation of regional authorities in the management and interaction with regional credit institutions by purchasing 
packages of securities of regional commercial banks, implementing schemes for establishing special statuses for regional banks (authorized bank, supporting bank, etc.) and creating conditions for increasing the attractiveness of lending real sectors of the economy of the regions of the Russian Arctic.

4) Develop state programs for subsidizing interest rates when lending by banking institutions to medium and small businesses operating in the Russian Arctic.

\section{CONCLUSION}

Investment activity of the banking sector plays an essential role in functioning and development of the regional economy.

In accordance with the tasks set, the study identified the following features and trends in the formation and use of the potential of credit institutions in the regions of the Russian Arctic:

- The regions of the Russian Arctic differ significantly in the level of development of banking systems, parameters of attracted capital and the degree of activity in the field of lending investment processes. At the same time, in recent years, all the Arctic regions of the Russian Federation have been characterized by a decrease in the number of regional credit institutions, and an expansion of large capital banks.

- The formed resource potential of credit institutions in the regions of the Russian Arctic is characterized by lower relative indicators in comparison with indicators in Russia. In the last decade, the growth rates of attracted resources in this group of regions were lower than the national average. In contrast to the all-Russian practice, in the structure of formed resources, funds of individuals prevail, however, the share of long-term deposits of the population in their volume has been decreasing in recent years.

- In most regions of the Russian Arctic (with the exception of Yamalo-Nenets Autonomous District), the intensity of using the potential of the banking sector, which is expressed through lending activity, is lower than the average for the Russian Federation. The lag is most clearly manifested in the intensity of lending to the small and medium-sized business sector.

- In several regions of the Russian Arctic (Murmansk and Arkhangelsk Regions, the Republics of Komi and Karelia), there is a situation when the volume of lending to the real sector of the economy does not correspond to the formed financial potential of credit institutions, which creates conditions for the outflow of financial resources from these regions.

The highlighted features of the formation and use of the potential of credit institutions made it possible to formulate the main recommendations for enhancing the participation of the banking sector in investment processes, which are based on increasing the interest of banking institutions in cooperation with enterprises and organizations of the Russian Arctic regions, supporting regional banks specializing in lending to subjects of the real sector of the economy, concentration of resources to invest in large infrastructure and production projects in the Russian Arctic.

The findings can be used to improve the policy of the Central Bank of the Russian Federation in the field of regulation of the activities of regional banks, as well as in the development of government measures aimed at enhancing investment processes in the Russian Arctic.

\section{AUTHORS' CONTRIBUTIONS}

The authors made an equal contribution to the study: collection and analysis of material; definition of goals and objectives, research methods; formulation and scientific substantiation of conclusions, registration of key research results in the form of an article.

\section{ACKNOWLEDGMENTS}

The study was carried out within the framework of the research project AAAA-A18-1180515901173 'Scientific Foundations for Formation and Implementation of Financial and Investment Potential of regions of the North and the Arctic'.

\section{REFERENCES}

[1] I.V. Naumov, "Role of financial resources of the economy's banking sector in Russian regions' socio-economic development", Economic and Social Changes: Facts, Trends, Forecast, 2020, vol. 6(13), pp. 152-168. 
DOI: 10.15838/esc.2020.6.72.9

[2] I.Sh. Urmancheev, "Increasing the role of Russian banks in the investment activity of the real sector of economy", Problems of Modern Economics, 2017, vol. 2(62), pp. 151-156. (In Russ.).

[3] Data from the official website of Rosstat [Dannyye s ofitsial'nogo sayta Rosstata], Rosstat official website. (In Russ.). Retrieved from

https://rosstat.gov.ru/investment_nonfinancial

[4] K. Indus, "The role and place of financial resources for the development of regions", Baltic journal of economic studies, 2018, vol. 3(4), pp. 94-98. DOI: 10.30525/22560742/2018-4-3-94-98

[5] L.R. Kurmanova, L.K. Kurbanaeva, D.A. Kurmanova, R.G. Khabibullin, "The role and place of financial resources for the development of regions. Social and cultural transformations in the context of modern globalism (SCTCGM 2018)", European Proceedings of Social and Behavioural Sciences, 2019, vol. 58, pp. 990-999. DOI: 10.15405/epsbs.2019.03.02.114

[6] V. Poletaeva, T. Panova, B. Tursunov, T. Mamakhatov, M. Kurbonalizoda, "On The Bank Financing Development Mechanisms for Processes of Formation of Sustainable Industrial Growth Economy in Russia”, in Proceedings of the 33rd International Business Information Management Association Conference, IBIMA 2019: Education Excellence and Innovation Management through Vision 2020, 33, Education Excellence and Innovation Management through Vision, 2020, pp. 6874-6881.

[7] V.N. Myakshin, A.V. Plastinin, "Investment attractiveness of the North-Arctic region: estimation, tools, management mechanisms", Lesnoy Zhurnal (Russian Forestry Journal), 2015, vol. 2(344), pp. 159-169. (In Russ.).

[8] E.A. Verbinenko, R.V. Badylevich, "Financial and credit system of the region: contents and value for formation of financial base of the territorial subject of the Russian Federation", Management of economic systems: electronic scientific journal [Upravleniye ekonomicheskimi sistemami: elektronnyy nauchnyy zhurnal], 2018, vol. 11 (117), p. 11. (In Russ.).

[9] E.A. Verbinenko, R.V. Badylevich, "Effect of the banking system on the economic development of the Russian Arctic regions", IOP Conference Series: Earth and Environmental Science, 2019, p. 012140. DOI: $10.1088 / 1755-1315 / 302 / 1 / 012140$

[10] Statistical data of the Central Bank of the Russian Federation [Statisticheskiye dannyye Tsentral'nogo Banka Rossiyskoy Federatsii (2021)], The official website of the Central Bank of the Russian Federation, 2021. (In Russ.). Retrieved from https://cbr.ru/statistics/bank_sector/sors/

[11]R.V. Badylevich, E.A. Verbinenko, "Analysis of participation of banking institutions in the strategic development programs of the Russian Arctic", Arctic and North, 2020, vol. 41, pp. 520. (In Russ.). DOI: 10.37482/issn22212698.2020.41.5

[12]R.V. Badylevich, E.A. Verbinenko, "Regional banks in the Arctic zone of the Russian Federation: state and development trends", Fundamental research, 2021, vol. 7, pp. 5-12. (In Russ.). DOI: 10.17513/fr.43065 